\title{
Gambaran nyeri kepala primer pada mahasiswa angkatan 2013 Fakultas Kedokteran Universitas Sam Ratulangi Manado
}

\author{
${ }^{1}$ Yafet Tandaju \\ ${ }^{2}$ Theresia Runtuwene \\ ${ }^{2}$ Mieke A. H. N. Kembuan \\ ${ }^{1}$ Kandidat Skripsi Fakultas Kedokteran Universitas Sam Ratulangi Manado \\ ${ }^{1}$ Bagian Neurologi Fakultas Kedokteran Universitas Sam Ratulangi \\ Email: Yafet_106@yahoo.com
}

\begin{abstract}
This study aimed to obtain the profile of primary headache among medical students batch 2013 in University of Sam Ratulangi Manado. This was a descriptive study. The headache description was assessed with questionnaires (Pain questionnaires PERDOSSI). There were 176 respondents consisted of 45 males and 131 females. The percentages of each headache type were as follows: tension-type $64 \%$, migraine without aura $20 \%$, migraine with aura $15 \%$, and cluster headache $1 \%$. The results showed that stress triggered $84 \%$ of headache cases. There were $73 \%$ of respondents who suffered from headache had family history of headache.
\end{abstract}

Keywords: primary headache, types of headache

\begin{abstract}
Abstrak: Penelitian ini bertujuan untuk mendapatkan gambaran nyeri kepala primer pada mahasiswa kedokteran Universitas Negeri Sam Ratulangi angkatan 2013. Jenis penelitian ini deskriptif. Deskripsi nyeri kepala pada responden dinilai dengan kuesioner (kuesioner nyeri PERDOSSI ). Terdapat 176 responden, terdiri dari 45 responden laki-laki dan 131 responden perempuan. Persentase untuk setiap jenis sakit kepala ialah sebagai berikut: tipe tegang 64\%, migraine tanpa aura 20\%, migrain dengan aura 15\%, dan nyeri kepala klaster $1 \%$. Hasil penelitian menunjukkan bahwa stres memicu 84\% dari kasus nyeri kepala. Pada penelitian ini didapatkan $73 \%$ dari responden yang menderita serangan nyeri kepala memiliki riwayat keluarga sakit kepala.
\end{abstract}

Kata kunci: nyeri kepala primer, jenis sakit kepala

Hampir semua orang pernah merasakan nyeri kepala. Sifat nyerinya digambarkan berbeda oleh setiap orang. Ada yang mengatakan rasanya seperti ditusuk-tusuk atau kepala terasa tertindih oleh beban yang berat; keluhan yang beraneka ragam menimbulkan teka-teki di kalangan mayarakat apa nyeri kepala itu sebenarnya. ${ }^{1}$

Nyeri kepala merupakan keluhan umum yang sering ditemukan dalam praktek umum. Prevalensi seumur hidup nyeri kepala lebih besar dari 90\%. Kebanyakan pasien yang datang dengan nyeri kepala memiliki 1 dari 3 ciri-ciri sindrom nyeri kepala berikut: migraine, nyeri kepala klaster, atau nyeri kepala tipe tegang. Nyeri kepala harus dibedakan dengan pusing (vertigo) dan perasaan melayang (dizzines atau light headedness). ${ }^{2}$

Disamping masalah medis nyeri kepala juga menimbulkan dampak sosial ekonomi seperti berkurangnya waktu efektif kerja, permasalahan rumah tangga, ketergantungn obat, dan lainny. Dengan demikian, tujuan umum penatalaksanaan nyeri kepala tidak saja untuk mengurangi nyeri, namun juga 
dalam menyelesaikan masalah sosial ekonomi yang dihadapinya. ${ }^{3}$

Suatu penelitian di New York mendapatkan nyeri kepala pada laki laki sebanyak 22\% dan perempuan $78 \%$. Menurut etnis didapatkan sebagai berikut: etnis Kaukasia 44\%, Hispanik 31\%, AfroAmerika 12\%, dan Asia 6\%. ${ }^{4}$ Dilain pihak, dari suatu penelitian berbasis populasi di Singapura diperoleh hasil penderita nyeri kepala pada laki laki $47 \%$ dan pada perempuan 53\% dengan perbedaan suku: Cina 79\%, Melayu 14\%, India 6\% dan lainnya $1 \% .{ }^{5}$ Di Indonesia dari penelitian di RS Cipto Mangunkusumo Jakarta periode Januari sampai dengan Mei 1986 didapatkan $17,4 \%$ pasien baru dengan keluhan utama nyeri kepala. ${ }^{5}$

Pada penelitian kali ini akan difokuskan pada nyeri kepala primer. Di Manado belum ada data epidemiologi mengenai nyeri kepala primer. Data mengenai sosiodemografiknya pun belum ada. Penelitian ini bertujuan untuk mendapatkan gambaran nyeri kepala primer yang tersebar di Manado, lebih khususnya pada mahasiswa kedokteran di Fakultas Kedokteran Universitas Sam Ratulangi.

\section{METODE PENELITIAN}

Penelitian ini menggunakan metode deskriptif untuk mendapatkan prevalensi nyeri kepala primer pada mahasiswa Kedokteran Universitas Sam Ratulangi Manado angkatan 2013. Populasi penelitian ini ialah seluruh mahasiswa Kedokteran Universitas Sam Ratulangi Manado angkatan 2013. Sampel penelitian ini ialah Mahasiswa Kedokteran Universitas Sam Ratulangi Manado angkatan 2013, yang aktif datang mengikuti kuliah.

Kriteria inklusi penelitian ini ialah mahasiswa yang bersedia mengisi kuisioner serta kooperatif dalam mengisi kuisioner. Kriteria eksklusi penelitian ini ialah mahasiswa yang mempunyai riwayat cedera kepala, mahasiswa yang tidak hadir, izin atau sakit.

Variabel penelitian terdiri dari variabel bebas yang meliputi karakteristik sosiodemografik, karakteristik klinis, riwayat nyeri kepala pada keluarga sedangkan variabel tergantung yaitu nyeri kepala tipe tegang, migraine dengan aura, migraine tanpa aura dan nyeri kepala klaster.

Pengambilan sampel penelitian ini yaitu mengambil seluruh mahasiswa Kedokteran Universitas Negeri Sam Ratulangi Manado angkatan 2013 yang memenuhi kriteria. Gambaran nyeri kepala responden diukur dengan kuesioner (kuesioner nyeri PERDOSSI). Data disajikan dalam bentuk tabel dan persentasi untuk melihat gambaran nyeri kepala.

\section{HASIL PENELITIAN}

Berdasarkan penelitian yang di lakukan pada mahasiswa kedokteran Universitas Negeri Sam Ratulangi yang berjumlah 220 orang mahasiswa, didapatkan 200 orang pernah mengalami nyeri kepala. Yang memenuhi kriteria inklusi sebanyak 176 orang mahasiswa.

\section{Distribusi responden berdasarkan jenis kelamin dan usia}

Dari 176 responden, didapatkan bahwa 131 orang $(74,4 \%)$ berjenis kelamin perempuan, sedangkan sisanya yaitu 45 orang $(25,6 \%)$ berjenis kelamin laki laki

Tabel 1. Distribusi responden berdasarkan jenis kelamin

\begin{tabular}{lcc}
\hline & Frekuensi & $\%$ \\
\hline Laki - laki & 45 & 25,6 \\
Pererempuan & 131 & 74,4 \\
Total & 176 & 100 \\
\hline
\end{tabular}

\section{Distribusi responden berdasarkan usia}

Pada penelitian ini didapatkan jumlah responden yang berusia 17-19 tahun sebanyak 60 orang $(34,1 \%)$, dan responden yang berusia 20-23 sebanyak 116 orang (65,9\%).

Berdasarkan Gambar 1 dapat dilihat bahwa kelompok usia yang paling banyak ialah kelompok usia 20-23 tahun. 


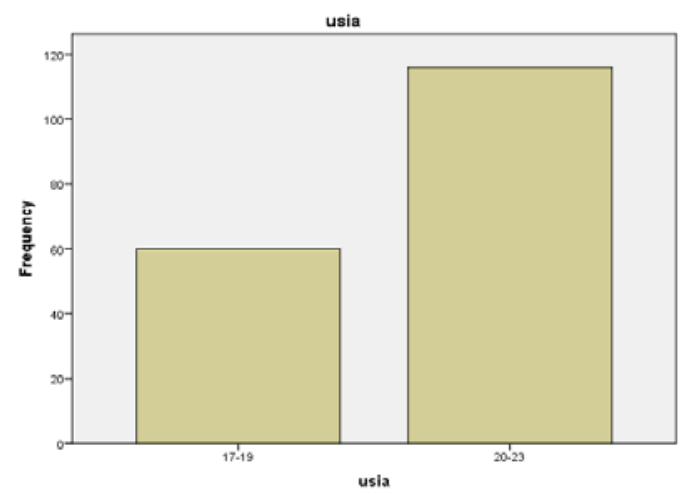

Gambar 1. Distribusi Responden berdasarkan Usia

\section{Distribusi Responden Berdasarkan Riwayat Nyeri Kepala dalam Keluarga}

Dari 176 responden didapatkan bahwa 130 orang $(73 \%)$ memiliki riwayat nyeri kepala dalam keluarga sedangkan responden yang tidak memiliki riwayat nyeri kepala dalam keluarga sebanyak 46 orang (27\%) (Tabel 2).

Tabel 2. Distribusi responden berdasarkan riwayat nyeri kepala dalam keluarga

\begin{tabular}{lcc}
\hline $\begin{array}{l}\text { Riwayat nyeri } \\
\text { kepala dalam } \\
\text { Keluarga }\end{array}$ & Frekuensi & $\%$ \\
\hline Ya & 130 & 73 \\
Tidak & 46 & 27 \\
Total & 176 & 100 \\
\hline
\end{tabular}

Distribusi Faktor pecetus serangan nyeri kepala

Dalam penelitian ini stres mencetus serangan nyeri kepala terbanyak yaitu pada 149 orang (84,6\%), sedangkan faktor pencetus yang paling sedikit ditemukan ialah perubahan cuaca yang mempengaruhi 34 orang (19,3\%) (Tabel 3).

\section{Karakteristik Berdasaran Jenis Nyeri Kepala}

Karakteristik jenis nyeri kepala primer yang didapat dalam penelitian ini responden dengan nyeri kepala tipe tegang ditemukan terbanyak dengan jumlah 113 $(64,2)$, nyeri kepala migraine tanpa aura $34(19,3 \%)$, migraine dengan aura 27(15,3\%), dan nyeri kepala klaster $2(1,1 \%)$.

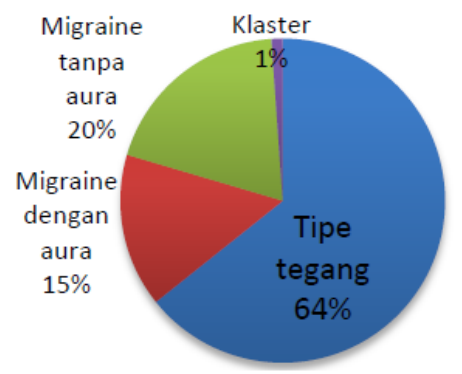

Gambar 2. Distribusi Jenis Nyeri Kepala

Tabel 3. Distribusi faktor resiko pencetus nyeri kepala

\begin{tabular}{lcc}
\hline Pencetus & Frekuensi & $\%$ \\
\hline Stress & 149 & 84,6 \\
Perubahan pola tidur & 110 & 62,5 \\
Melewatkan waktu makan & 74 & 42 \\
Menstruasi & 66 & 37,5 \\
Asap rokok & 68 & 38,6 \\
Perubahan cuaca & 34 & 19,3 \\
Menonton/bermain laptop & 56 & 31,8 \\
\hline
\end{tabular}

\section{BAHASAN}

Berdasarkan jenis kelamin, nyeri kepala primer pada penelitian ini didapatkan lebih banyak terjadi pada perempuan 131(74,4\%) dibandingkan dengan laki-laki 45 (25,6\%). Hal ini tidak jauh berbeda dengan penelitian yang dilakuan di Maryland tahun 1994 yang menggambarkan prevalensi nyeri kepala didapatkan perempuan 53\% dan laki-laki $27,5 \%$ untuk paien dengan nyeri kepala primer. ${ }^{6}$

Pencetus tebanyak dari nyeri kepala primer pada mahasiswa kedokteran 
Universitas Sam Ratulangi Manado yaitu stres (84\%), menstruasi pada perempuan (37,5\%), dan yang paling rendah ialah perubahan cuaca (19\%). Stres bisa menyebabkan hiperventilasi pernafasan sehingga kadar $\mathrm{CO}_{2}$ dalam darah menurun, terjadi alkalosis yang selanjutnya akan mengakibatkan ion kalsium masuk kedalam sel dan menimbulkan kontraksi otot berlebihan sehingga terjadi nyeri kepala. ${ }^{7,8}$

Nyeri kepala tipe tegang dalam penelitian ini mempunyai persentase terbanyak (64,2\%). Penelitian ini sesuai dengan teori yang menyatakan bahwa nyeri kepala tipe tegang (TTH) ialah yang paling umum dengan prevalensi pada populasi umum berkisar antara 30\% dan $78 \%$ dalam studi yang berbeda. ${ }^{8}$

Nyeri kepala tipe migraine tanpa aura pada penelitian ini sebanyak 19,3\%, sedangkan migraine dengan aura sebanyak 15,3\%. Hasil ini tidak jauh berbeda dengan penelitian yang dilakukan pada 238 mahasiswa kedokteran dengan menggunakan kuesioner di Santa Casa School of Medicine of São Paulo, Brazil, yang mendapatkan persentae nyeri kepala migraine dengan dan tanpa aura sebanyak $40,2 \%{ }^{9}$

Nyeri kepala klaster paling sedikit didapat $(1,1 \%)$. Dalam penelitian ini nyeri kepala klaster terjadi lebih banyak pada perempuan, hal ini tidak sesuai dengan teori yang ada, dimana perbandingan antara laki-laki dan perempuan 6:1.

\section{SIMPULAN DAN SARAN}

Dalam penelitian ini ditemukan responden dengan riwayat nyeri kepala pada keluarga berisiko lebih besar terserang nyeri kepala. Jenis nyeri kepala terbanyak ialah nyeri kepala tipe tegang sedangkan jenis nyeri kepala yang paling sedikit ditemukan ialah nyeri kepala klaster. Stres menjadi pemicu sebagian besar serangan nyeri kepala.

\section{DAFTAR PUSTAKA}

1. Sidharta. Anamnesa Kasus sakit kepala. In: tata pemeriksaan klinik neurologi. Jakarta: PT. Dian rakyat 2006:32.

2. Tejas R. Facial pain and headahce. [cited 21 September 2015]. Available from: http://emedicine.medscape.com/ article/1048596-overview .

3. Harsono. Buku Ajar Neurologi Klinis. Yogyakarta: Gadjah Mada University Press.

4. Fitriyanti M. Gambaran nyeri kepala primer di Poliklinik Saraf BLU Prof. Dr. R. D. Kandou Manado [Skripsi]. Manado:Universitas Sam Ratulangi; 2011.

5. Sjahrir H. Mekanisme terjadinya nyeri kepala primer. [cited 23 September 2015]. Available from: http://respitory.usu.ac.id/bitstream/ne urologi-hassan-pdf.

6. Rozen TD, Fishman RS. Female cluster headache in the United States of America: what are the gender differences? Results from the United States Cluster Headache Survey. J Neurol Sci. 2012;317(1-2):17-28.

7. Turana Y. Nyeri kepala karena ketegangan otot. [cited 22 Januari 2016]. Available from: http://www.medikaholistik.com/medi ka.html.

8. Stovner LJ, Hagen $K$, Jensen $R$, Katsarava Z, Lipton RB, Scher AI, et al. The global burden of headache: a documentation of headache prevalence and disability worldwide. Cephalalgia. 2007;27:193-210.

9. Deleu D, Khan MA, Humaidan H, Al Mantheri Z, Al Hashami S. Prevalence and clinical characteristics of headache in medical students in Oman. Department of Clinical Pharmacology and Therapeutics, Sultan Qaboos, Oman. [cited 22 Januari 2016]. Available from: http://www.ncbi.nlm.nih.gov/ pubmed/11576205t.

10. Hsu LC, Wang SJ, Fuh JL. Prevalence and impact of migrainous vertigo in mid-life women: a community-based study. Cephalalgia. 2011;31(1):77-83. 